\title{
OPTIMALISASI PEMANFAATANLIMBAH BONGGOL JAGUNG UNTUK BUDIDAYA JAMUR MERANG BAGI PEMUDA DESA TAMBAKMERAK KABUPATEN BOJONEGORO
}

\author{
Elika Febriati ${ }^{1}$, Febri Novita Sari $^{2}$, Elana Firdayanti ${ }^{3}$, Ilham Muchtar Ashari ${ }^{4}$, Heri \\ Mulyanti $^{5}$ \\ Fakultas Ekonomi, Universitas Bojonegoro ${ }^{1}$ \\ Fakultas Ilmu Sosial dan Ilmu Politik, Universitas Bojonegoro ${ }^{2}$ \\ Fakultas Ekonomi, Universitas Bojonegoro ${ }^{3}$ \\ Fakultas Pertanian, Universitas Bojonegoro ${ }^{4}$ \\ Fakultas Sain dan Teknik, Universitas Bojonegoro ${ }^{5}$ \\ elikafebrianti99@gmail.com ${ }^{1}$, febri.novitasariii@gmail.com ${ }^{2}$, elianafirdian22@gmail.com ${ }^{3}$, \\ ilhammuchtarasari1234@gmail.com ${ }^{4}$,izzatafirdausa@gmail.com ${ }^{5}$
}

\begin{abstract}
ABSTRAK
Pemanfaatan limbah bonggol jagung untuk budi daya jamur merang merupakan upaya untuk mengurangi limbah hasil pertanian yaitu dari komoditas jagung. Agar budi daya jamur merang media bonggol jagung dapat memperoleh hasil yang maksimal maka perlu adanya pengoptimalisasian. Optimalisasi yang dilakukan dalam pemanfaatan bonggol jagung yaitu dengan memberikan pendampingan, dan pelatihan melalui penyuluhan, praktek, dan demonstrasi meliputi persiapan bahan, formulasi medium, pembuatan medium pertumbuhan jamur, dan manajemen pemeliharaan jamur. Metode yang dilakukan dalam pengabdian ini yaitu penyuluhan, praktek, dan pendampingan. Hasil pengabdian yang dapat dilihat dari segi dampak sosial ekonomi yaitu mampu memberikan motivasi kepada pemuda maupun masyarakat untuk lebih kreatif dalam berkarya melalui pemanfaatan barangbarang di sekitar karena selama ini belum pernah mendapatkan pengarahan ataupun motivasi yang memacu ekonomi kreatif warga. Serta, mampu menjadi pembuka cakrawala berpikir masyarakat untuk dapat memanfaatkan barang bekas atau limbah lainnya agar bernilai ekonomi, sehingga dapat dikonsumsi untuk sendiri maupun dipasarkan. Pengabdian ini dapat dikatakan berhasil ketika terdapat perubahan pengetahuan dan keterampilan masyarakat mengenai formulasi, pembuatan media pertumbuhan, serta teknik budidaya jamur merang memanfaatkan bonggol jagung.
\end{abstract}

Kata Kunci : bonggol jagung, jamur merang, karang taruna

\begin{abstract}
Utilization of corncobs waste for straw mushroom cultivation is an effort to reduce agricultural waste from corn commodities. In order for the mushroom cultivation of corn cobs media to obtain maximum results, it is necessary to optimize. Optimization carried out in the utilization of corncobs is to provide assistance, and training through counseling, practice, and demonstrations include preparation of materials, medium formulation, manufacture of mushroom growth media, and management of mushroom maintenance. The method used in this service is counseling, practice, and mentoring. The results of dedication that can be seen in terms of socio-economic impact that is able to provide motivation to youth and the community to be more creative in working through the use of goods around because so far there has never been any direction or motivation that stimulates the creative economy of citizens. And, being able to be an opening horizon of people's thinking to be able to use used goods or other waste so that it has economic value, so it can be consumed for itself or marketed. This dedication can be said to be successful when there is a change in people's knowledge and skills regarding formulation, making growth media, and straw mushroom cultivation techniques utilizing corncobs.
\end{abstract}

Keywords : corncobs, straw mushrooms, youth clubs 


\section{PENDAHULUAN}

Indonesia merupakan salah satu negara agraris (agriculture country) yang setiap tahunnya menghasilkan limbah pertanian yang sangat melimpah seperti jerami padi, bonggol jagung, batang kedelai, kulit pisang dan lain - lain(Abbas and Muhtarom 2018; Abid Muhtarom; Tri Haryanto; Nurul Istifadah 2019; Muhtarom and Haryanto 2018). Limbah hasil pertanian tersebut masih mengandung sejumlah senyawa yang dapat dikonversi menjadi produk yang memiliki nilai ekonomi seperti kompos, pakan ternak atau digunakan sebagai medium pertumbuhan mikroba (Meryandini 2009).

Jagung merupakan komoditas palawija utama di Indonesia ditinjau dari aspek pengusahaan dan penggunaan hasilnya, yaitu sebagai bahan baku pangan dan pakan. Kebutuhan jagung terus meningkat seiring dengan meningkatnya permintaan bahan baku pakan. Komposisi bahan baku pakan ternak unggas membutuhkan jagung sekitar $50 \%$ dari total bahan yang diperlukan. Dilihat dari segi permintaan jagung yang terus meningkat, tentu diiringi dengan limbah yang dihasilkan akibat pemanfaatan jagung tersebut tidak terkecuali adalah bonggol jagung (Janggel).

Bonggol jagung merupakan sisa pengolahan industri pertanian pada jagung yang jumlahnya akan terus bertambah seiring dengan peningkatan kapasitas produksi.Kandungan pada bonggol jagung dapat dihitung dengan menggunakan nilai Residue to Product Ratio (RPR) bonggol jagung adalah 0,273 (pada kadar air 7,53\%) dan nilai kalori $4451 \mathrm{kkal} / \mathrm{kg}$ (Koopmans and Koppejan, 1997; Sudradjat, 2004). Berdasarkan kandungan yang dimiliki bonggol jagung tersebut, bonggol jagung yang selama ini hanya dimanfaatkan sebagai bahan baku pembakaran tradisional, pembuatan arang dan pakan ternak ternyata dapat digunakan sebagai media tanam jamur merang (Sunandar, 2010).

Pemanfaatan limbah hasil panen adalah salah satu alternatif menjaga kebersihan lingkungan dari pencemaran disamping untuk kreativitas dan peningkatan sumber perekonomian baik dalam negeri maupun luar negeri (Wandi Abbas 2018). Adapun pemanfaatan limbah secara maksimal yang dibuktikan dengan beberapa penelitian yaitu telah dilakukan terkait dengan pemanfaatan limbah hasil panen seperti penelitian Artiyani (2012) yang memanfaatkan limbah kulit singkong menjadi paving block; Hasanah, dkk (2014) memanfaatkan limbah tanaman jagung dan kulit coklat sebagai pupuk organik; juga penelitian Pratiwi, Lestari, \& Widianto memanfatkan limbah buah salak sebagai substrat Nata De Salacca. Dari beberapa penelitian tersebut jelas bahwa terdapat nilai positif dari 
kreativitas memanfaatkan limbah hasil panen bahkan limbah menjadi tinggi nilai ekonominya manakala dikelola secara tepat.

Perlu adanya upaya optimalisasi dalam memanfaatkan limbah hasil pertanian tersebut sehingga bisa meningkatkan kreatifitas masyarakat desa dengan hasil yang dapat digunakan sendiri maupun dipasarkan. Sumber daya alam yang melimpah serta kondisi lingkungan yang mendukung, budidaya jamur merang merupakan suatu peluang usaha mempunyai prospek bagus untuk dikembangkan di desa tersebut. Jamur pangan (edibel) berprospek cerah untuk dibudidayakan karena berharga mahal dan berpeluang untuk diekspor (Sinaga, 2001). Optimalisasi pemanfaatan bonggol jagung pada Pemuda Karang Taruna Desa Tambakmerak merupakan langkah strategis dalam pemanfaatan limbah hasil pertanian dalam meningkatkan kesejahteraan masyarakat desa tersebut.

Pemuda Karang Taruna Desa Tambakmerak Kecamatan Kasiman Kabupaten Bojonegoro memanfaatkan limbah bonggol jagung menjadi bahan yang memiliki nilai ekonomis tinggi yaitu jamur merang. Pemuda Karang Taruna lebih tertarik untuk membudidayakan usaha jamur merang dibanding lainya karena bukan hanya pada jamur merang yang bermutu bagus, akan tetapi juga dapat diproduksi menjadi krupuk, kripik, stik, dan lain-lain dengan harga yang relative tinggi, harga jamur relatif stabil dan tergolong tinggi jika dibandingkan jenis sayuran lainnya.

Jamur merang (Volvariella volvaceace) adalah salah satu hasil pertanian yang banyak dikembangkan dengan pesat pada dewasa ini, terutama didaerah pedesaan. Dalam perkembangannya jamur merang bukan hanya sebagai konsumsi sayur, akan tetapi juga dengan rekayasa teknologi pengolahan pangan, maka jamur merang dapat diproduksi menjadi produk olahan yang mempunyai nilai ekonomistinggi. Jamur merang dinilai dapat tumbuh dengan baik pada suhu $30^{\circ} \mathrm{C}-35^{\circ} \mathrm{C}$ dan jamur merang mengandung $25,9-28,5 \%$ protein lebih tinggi dibanding beras 7,38\%dan gandum 13,2\%. Selain kandungan protein, jamur merang juga memiliki kandungan lemak total 2,0 - 2,6\% dan karbohidrat 2,7 - 4,8\%. Jamur merang selain bisa dikonsumsi sebagai makanan juga bisa dimanfaatkan sebagai obat. (Widiastuti, 2007; Parjimo dan Andoko, 2007).

Hal ini sesuai dengan pendapat Suharjo (2010: 38) yang menyatakan bahwa jamur merang tergolong jamur konsumsi yang harga jualnya relatif stabil daripada harga jamur konsumsi lainnya. Harga jamur merang di pasaran sudah disesuaikan dengan harga yang berlaku di tingkat petani, yaitu untuk harga ditingkat pengepul itu sendiri Rp 15.000 - Rp 
16.000/Kg, harga tersebut sudah disesuaikan dengan harga pasar maupun biaya produksi yang digunakan untuk budidaya jamur merang. Bahkan, harga jamur merang diperkirakan akan terus naik seiring dengan meningkatnya permintaan.

Banyaknya bahan baku (Bonggol Jagung) yang tersedia di lingkungan dan mengingat banyaknya permintaan jamur merang oleh warga sekitar maupun keadaan pasar, mengakibatkan warga Desa Tambakmerak ingin mengembangkan usaha budidaya jamur merang tersebut lebih luas. Program Kreativitas Mahasiswa Pengabdian Masyarakat (PKMM) ini memiliki tujuan untuk meningkatkan pemahaman masyarakat Desa Tambakmerak mengenai pemanfaatan bonggol jagung sebagai media dalam budidaya jamur merang serta mengembangkan budidaya jamur merang dengan memanfaatkan bonggol jagung di Desa Tambakmerak Kecamatan Kasiman Kabupaten Bojonegoro sehingga optimalisasi pemanfaatan bonggol jagung untuk media budidaya jamur merang sebagai wujud tindak lanjut pengolahan limbah.

Adapun tujuan dari program ini untuk Meningkatkan pemahaman Masyarakat Desa Tambakmeral mengenai pemanfaatan bonggol jagung sebagai media dalam budidaya jamur merang serta Mengembangkan budi daya jamur merang dengan memanfaatkan bonggol jagung di Desa Tambakmerak Kecamatan Kasiman Kabupaten Bojonegoro.

\section{METODE}

Kegiatan Pengabdian ini adalah optimalisasi pemanfaatan bonggol jagung untuk budidaya jamur merang bagi Pemuda Karang Taruna Desa Tambakmerak Kecamatan Kasiman Kabupaten Bojonegoro. Pendampingan dilakukan disalah satu rumah warga. Metode yang digunakan pada kegiatan pengabdian ini adalah pelatihan melalui penyuluhan, praktek, demonstrasi meliputi persiapan bahan, formulasi medium, pembuatan medium pertumbuhan jamur, dan manajemen pemeliharaan jamur dan pendampingan

\section{Penyuluhan}

Dalam tahap penyuluhan sebagai penyampai materi adalah stakeholder dari UPT Dinas Pertanian Kecamatan Kasiman Bapak Durrahman,S.P. dan instruktur dari pelaku usaha budidaya jamur yang lebih berpengalaman dilaksanakan di Balai desa Tambakmerak. Kegiatan penyuluhan meliputi permasalahan limbah bonggol jagung serta peluangnya sebagai bahan baku medium pertumbuhan jamur merang, formulasi medium, cara pembuatan medium, manajemen pemeliharaan jamur, dan metode pemanenan. 
Dengan adanya teknik-teknik tersebut diharapkan warnga masyarakat lebih mudah dalam pengembangan usaha budidaya jamur merang baik dalam skala kecil maupun skala besar. Masyarakat pemuda karang taruna yang hadir diberikan pengarahan dan tata cara pembuatannya secara praktek langsung. Setelah itu, praktek dilakukan setelah siap menyediakan tempat dan bonggol jagung. Bahan-bahan yang diperlukan disediakan oleh tim pengabdian.

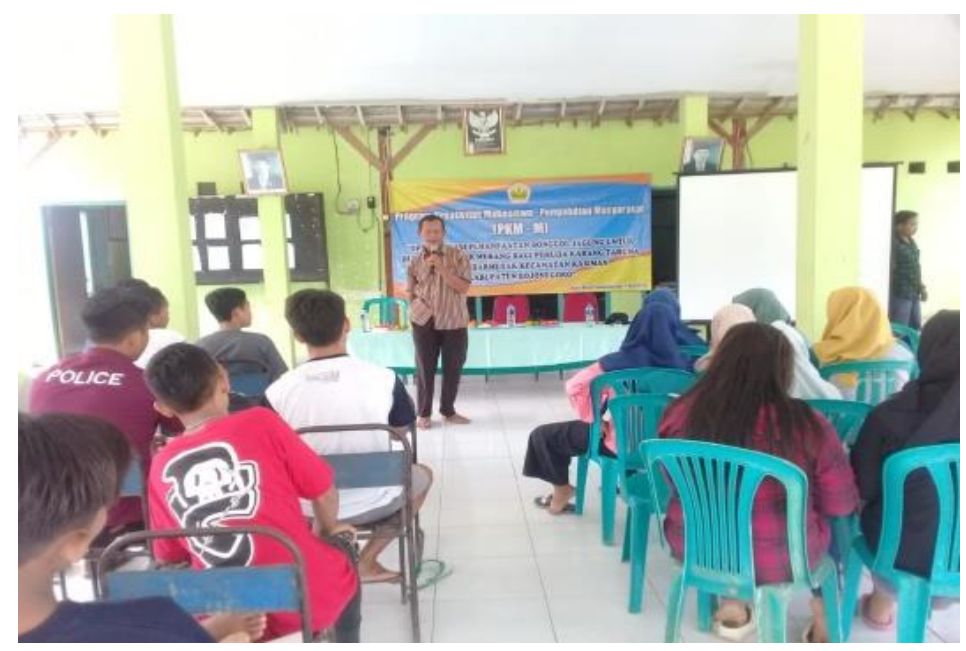

Gambar. 1. Penyuluhan

\section{Praktek}

Pembuatan medium pertumbuhan jamur merang memanfaatkan limbah bonggol jagung untuk mengembangkan usaha budidaya jamur meliputi persiapan bahan dan alat, pelatihan pembuatan medium, manajemen budidaya jamur merang serta pemanenan. Praktek bagian dari kegiatan pembuatan secara langsung dilaksanakan bersama dengan melibatkan pemuda Karang Taruna Desa Tambakmerak Kecamatan Kasiman Kabupaten Bojonegoro. Bahanbahan yang diperlukan dalam pembuatan jamur merang juga cukup mudah di dapat dan tidak memerlukan biaya mahal. Antara lain Bonggol jagung, Ragi 7 Butir, Bekatul 5 kg, Urea 1 kg, Karung Goni, Terpal Plastik, dan Papan.

Demonstrasi Bagian dari kegiatan sebagai peragaan atau pertunjukan tentang cara melakukan atau mengerjakan meliputi :

1) Siapkan tempat untuk menumpuk bonggol jagung tersebut dengan membuat kotak dari papan yang telah disediakan tadi dengan ukuran $5 \mathrm{~m} \times 1 \mathrm{~m}$. Letakkan karung goni sebagai alas janggel. Karung goni dipilih karena mempunyai bahan yang panas dan daya 
serap terhadap air cukup lama sehingga mampu menjaga kelembaban. Setelah tempat sudah siap untuk digunakan tumpuk bonggol jagung dengan tinggi lebih kurang $15 \mathrm{~cm}$.

2) Campurkan semua bahan yang telah disiapkan, yaitu ragi, bekatul, dan urea menjadi satu dan aduk rata. Kemudian taburkan secara merata dan secukupnya. Jangan dihabiskan, cukup setengah dari takaran yang sudah disiapkan tadi.

3) Tutup kembali dengan menggunakan bonggol jagung setinggi kurang lebih $15 \mathrm{~cm}$, kemudian taburkan kembali campuran ragi, bekatul, dan urea tadi sampai merata, dan habiskan semua campuran tersebut.

4) Setelah semua selesai dilakukan, siram dengan air bersih sampai basah, kemudian tutup rapat dengan menggunakan terpal.

5) Selanjutnya hanya perlu menunggu hingga beberapa hari ke depan untuk melihat apakah jamur dapat muncul atau tidak kurang lebih 12-15 hari.

6) Untuk menjaga kelembapan media tersebut, lakukan penyiraman secara rutin dan lokasi penempatan harus selalu terkena sinar matahari, tetapi terhindar dari hujan. Proses penyiraman bisa dicampur menggunakan pupuk urea. Dan lokasi pembibitan jamur jagung ini jangan di atas lantai atau keramik. Lokasi yang tepat adalah di atas tanah. Proses terakhir adalah masa panen. Jamur ini bisa dipanen ketika sudah berumur kurang lebih 15 hari dari terahir proses pembuatan tersebut. Panen bisa dilakukan pagi atau sore hari jika bentuk jamur sudah seperti jamur kedelai, berbentuk bulat.

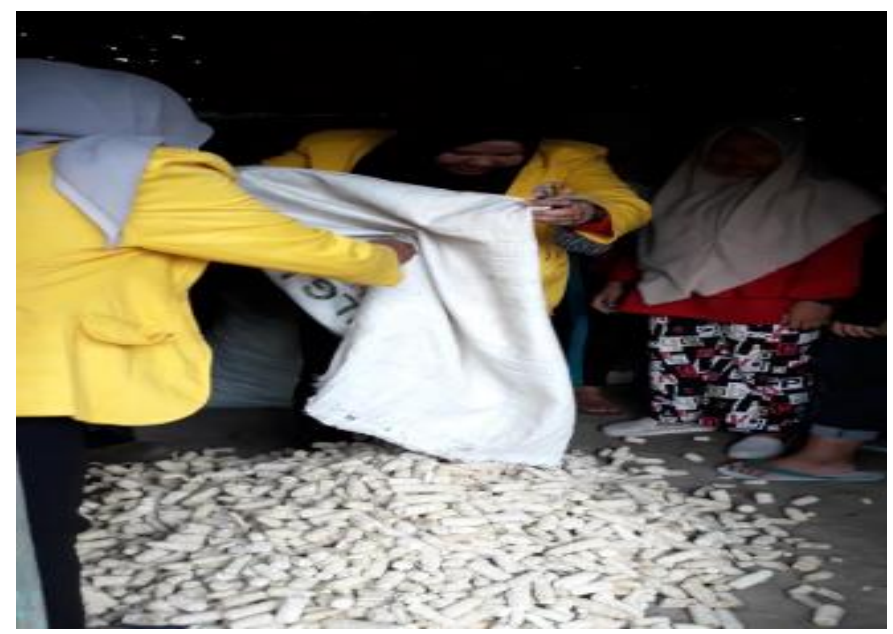

Gambar.2. Step 1 


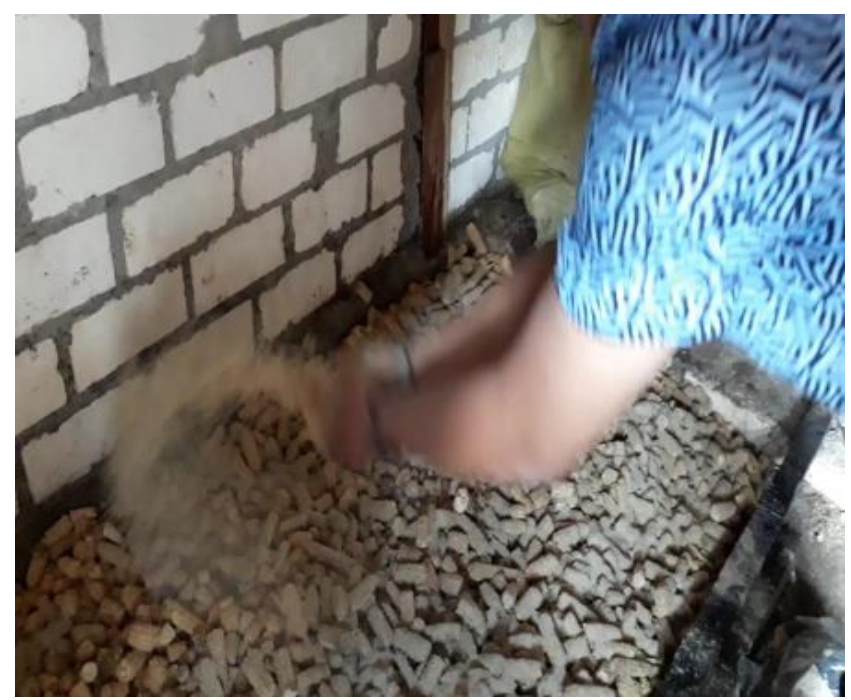

Gambar.3. Step 2

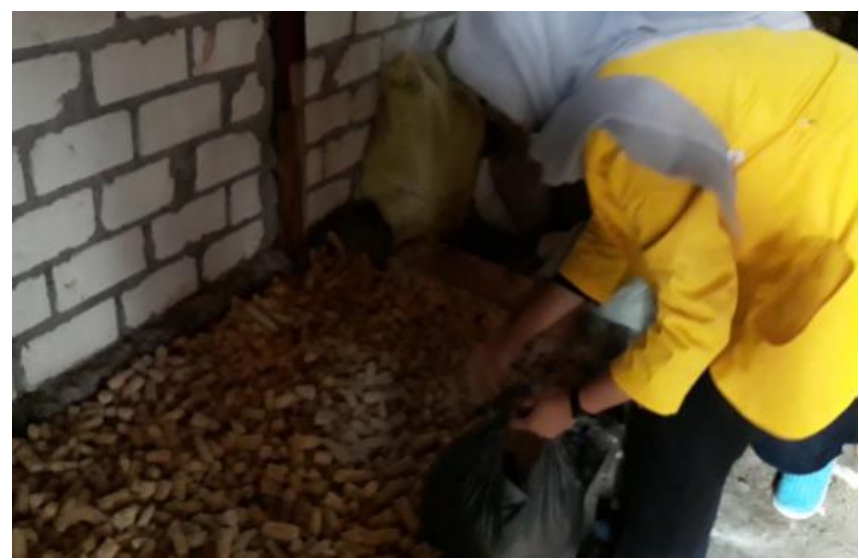

Gambar.4. Step 3

\section{Pendampingan}

Pendampingan dilaksanakan dengan membentuk sistem koordinasi antara mahasiswa dan ketua program dari masyarakat, yaitu Pemuda Karang Taruna Desa Tambakmerak Kecamatan Kasiman Kabupaten Bojonegoro. Evaluasi dilaksanakan setiap dua minggu sekali setelah pelatihan pembuatan kepada masyarakat. Pendampingan pasca pelatihan dilakukan sebagai proses evaluasi dan monitoring untuk melihat keberhasilan maupun pengarahan pemasaran yang sebaiknya dilakukan. Hasil awal pemanenan jamur janggel berkisar $3-4$ kilo dalam sekali panen. Jamur dapat dipanen setiap hari bisa pagi maupun sore. Sehingga dapat dikonsumsi untuk sendiri maupun dipasarkan. 


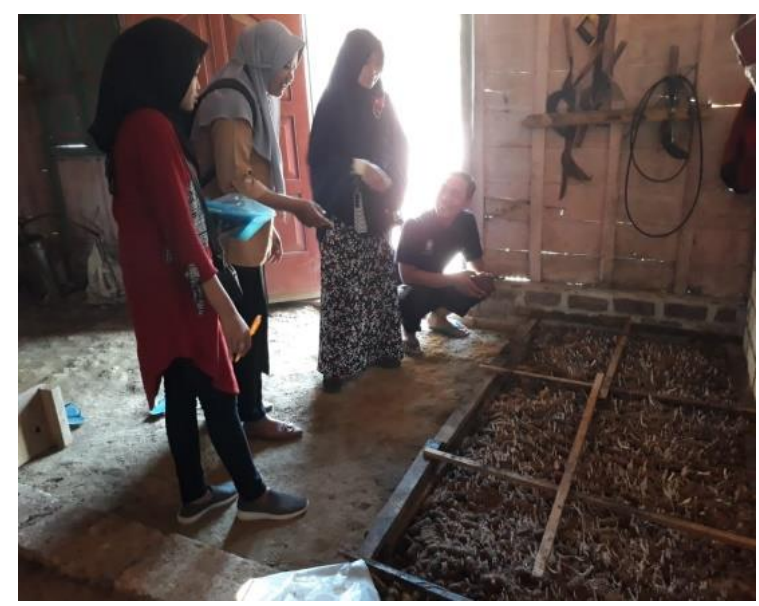

Gambar.5. Pendampingan

\section{HASIL DAN PEMBAHASAN}

Besarnya permintaan komoditi hasil pertanian jagung menjadikan petani harus menyediakan atau mampu mencukupi kebutuhan pangan jagung. Lingkungan yang strategis menjadi salah satu faktor keberhasilan hasil pertanian jagung dengan hasil yang maksimal. Sehingga menjadikan limbah dari jagung atau yang sering kita sebut bonggol jangung menjadi lebih banyak seiring dengan tingkat permintaan dari jagung tersebut. Dalam masyarakat pedesaan limbah jagung seringkali dibiarkanmenjadi tumpukan tanpa dimanfaatkan secara maksimal untuk mendapatkan nilai yang lebih.

Kurangnya pemanfaatan limbah pertanian secara maksimal menjadikan daya guna dan nilai suatu barang tersebut rendah. sehingga masyarakat sering membiarkan limbah tersebut dilingkungan sampai mengurai tanpa memiliki daya guna yang baik. Masyarakat pedesaan memanfaatkan bonggol jagung hanya sebagai bahan baku pembakaran tradisional (arang) dan pakan ternak. Sedangkan penggunaan atau pembakaran secara tradisional mulai berkurang. Penggunaan gas LPG lebih diminati masyarakat selain praktis pengunaanya, dalam gas tersebut terdapat subsidi dari pemerintah sehingga mampu dijangkau masyarakat bawah. Dengan beralihnya penggunaan tersebut, pemanfaatan bonggol jagung hanya sebagai pakan ternak. Tetapi tidak menutup kemungkinan pemanfaatan sebagai pakan ternak mampu menjadi satu-satunya solusi untuk mengurangi limbah pertanian bonggol jagung.

Pelaksanaan kegiatan pengabdian kepada masyarakat "Optimalisasi Pemanfaatan Bonggol Jagung Untuk Budi Daya Jamur Merang Bagi Pemuda Karang Taruna Desa Tambakmerak Kecamatan Kasiman Kabupaten Bojonegoro” sebagai peningkatan ekonomi 
maupun pengolahan limbah pertanian yang telah dilaksanakan dan hal yang masih berlangsung sampai saat ini adalah pendampingan terhadap program.

Mengingat banyaknya permintaan jamur merang oleh warga sekitar maupun keadaan pasar, warga desa Tambakmerak ingin mengembangkan usaha budidaya jamur tersebut lebih luas. Tentu kami mahasiswa ingin berperan lebih terhadap pengembangan budidaya jamur merang dari limbah pertanian yaitu bonggol jagung.Oleh karena itu adapun potensi-potensi capaian dari adanya program ini yaitu:

\section{Dampak Sosial Ekonomi}

Pengabdian ini memiliki harapan mampu bermanfaat sebagai motivasi untuk pemuda maupun masyarakat agar lebih kreatif dalam berkarya melalui pemanfaatan barang-barang di sekitar karena selama ini belum pernah mendapatkan pengarahan ataupun motivasi yang memacu ekonomi kreatif warga. Serta, kegiatan ini diharapkan menjadi pembuka cakrawala berpikir masyarakat untuk dapat memanfaatkan barang bekas atau limbah lainnya agar bernilai ekonomi, sehingga dapat dikonsumsi untuk sendiri maupun dipasarkan.

Keberhasilan kegiatan pengabdian pada masyarakat akan dievaluasi dengan melihat respon yang diberikan oleh peserta kegiatan, yang diukur melalui :

1. Perubahan pengetahuan dan keterampilan mengenai formulasi, pembuatan media pertumbuhan, serta teknik budidaya jamur merang memanfaatkan bonggol jagung.

2. Sampai berapa jauh peserta dapat melaksanakan teknik budidaya jamur merang setelah tiga bulan dari berakhirnya kegiatan Pengabdian Kepada Masyarakat.

Kegitan tersebut mampu diikuti dengan semangat antusis oleh pemuda karang taruna sebagai salah satu bentuk keingintahuan dan penjelasan dari penyuluhan sehingga mampu menjawab keraguan atau teka-teki dari pemanfaatan bonggol jagung sebagai media jamur merang tersebut. Karena dalam pangsa pasar yang dijelaskan, Hal ini sesuai dengan pendapat Suharjo (2010: 38) yang menyatakan bahwa jamur merang tergolong jamur konsumsi yang harga jualnya relatif stabil dari pada harga jamur konsumsi lainnya. Harga jamur merang di pasaran sudah disesuaikan dengan harga yang berlaku di tingkat petani, yaitu untuk harga di tingkat pengepul itu sendiri Rp 15.000 - Rp 16.000/Kg, harga tersebut sudah disesuaikan dengan harga pasar maupun biaya produksi yang digunakan untuk budi daya jamur merang. Bahkan, harga jamur merang diperkirakan akan terus naik seiring dengan meningkatnya permintaan. 
Indikator ketercapaian program ditinjau berdasarkan didaftarkannya usaha budidaya jamur merang dengan media janggel secara legal. Sehingga produksi jamur merang dapat menjadi produk unggulan daerah setempat. Dalam masa panjang keberhasilan program ini dapat dilihat mengenai melalui jumlah usaha budidaya Jamur Merang yang ada Di Desa Tambakmerak Kecamatan Kasiman Kabupaten Bojonegoro. Semoga program pengabdian ini benar-benar dapat terlaksana dengan baik.

\section{SIMPULAN}

Optimalisasi pemanfaatan limbah bonggol jagung untuk budi daya jamur merang bagi pemuda Desa Tambakmerak Kabupaten Bojonegoro merupakan upaya untuk mengurangi limbah hasil pertanian yaitu dari komoditas jagung. Berdasarkan dari hasil pengabdian, dapat diketahui bahwa masyarakat di Desa Tambakmerak terutama pemuda dalam hal ini Karang Taruna sebenarnya sudah berupaya untuk melakukan inovasi dalam memanfaatkan limbah dari hasil pertanian yaitu bonggol jagung. Menjadikan bonggol jagung sebagai media tanam jamur merang merupakan inovasi yang akan mempunyai banyak manfaat, karena dalam perkembangannya jamur merang bukan hanya dimanfaatkan sebagai konsumsi sayur, akan tetapi juga dengan rekayasa teknologi pengolahan pangan, maka jamur merang dapat diproduksi menjadi produk olahan yang mempunyai nilai ekonomis tinggi. Namun, dalam pemanfaatan limbah bonggol jagung tersebut, masyarakat di Desa Tambakmerak dihadapkan oleh berbagai kendala dalam proses budi daya jamur merang, hal disebabkan karena kurangnya pemahaman dan pengetahuan. Untuk itu melalui pengabdian ini tim melakukan pengoptimalisasian pemanfaatan bonggol jagung dengan memberikan pendampingan, dan pelatihan melalui penyuluhan, praktek, dan demonstrasi. Dimana penyuluhan tersebut sesuai menjelaskan mengenai kandungan dari bonggol jagung jagung dan bahan-bahan lainya sehingga teka-teki masyarakat selama ini terjawab dan menjadi suatu pengetahuan akan manfaat bonggol jagung tersebut. Tahapan program ini mulai dari persiapan bahan, pembuatan medium pertumbuhan jamur, dan manajemen pemeliharaan jamur. hal ini diharapkan agar budi daya jamur merang media bonggol jagung dapat berkembang secara luas sehingga memperoleh hasil yang maksimal dimana nanti hasilnya bisa untuk dikonsumsi sendiri maupun dipasarkan. 


\section{DAFTAR PUSTAKA}

Abbas, Wandi, and Abid Muhtarom. 2018. "DEVELOPMENT OF AGRICULTURE SECTOR IN POVERTY REDUCTION IN EAST JAVA (Study of GKS Plus GERBANGKARTASUSILA Plus Period 2010-2017)." International Journal of Economics Management and Social Science 1(1):1-8.

Abid Muhtarom, Tri Haryanto, Nurul Istifadah. 2019. “ANALYSIS OF PRODUCTIVITY EFFICIENCY OF FOOD PLANT AGRICULTURE IN EAST." International Journal of Civil Engineering and Technology (IJCIET) 10(1)"420-43.

Muhtarom, Abid and Tri Haryanto. 2018. Agriculture Land and Technology: Agricultural Production in The Welfare Improvement.

Wandi Abbas, Abid Muhtarom. 2018. "PEMANFAATAN BANTUAN LUAR NEGERI DALAM PENINGKATAN EKONOMI KERAKYATAN TANI KAKAO DI PROVINSI SULAWESI BARAT (Studi Program Swisscontact Periode 2013-2018)". Jurnal Penelitian Ilmu Manajemen III(1):638-50.

Budhi Widiastuti. 2007. Budidaya jamur kompos, jamur Bandung, Balai Pengkajian Teknologi PertanianAgro Media Pustaka. jamur kuping, jamur tiram, dan jamur merang.

Parjimo dan Agus Andoko. 2007. Budidaya jamur,merang dan jamur kancing. Penebar Swadaya.Kementerian Pertanian.Jawa Barat. 86 hal.Jawa Barat, Balai Besar Pengkajian Dan Penelitian Dan Pengembangan Pertanian

Randy R. Wrihatnolo dan Riant Nugroho Dwidjowijoto. 2007. Manajemen Pemberdayaan Sebuah Pengantar dan Panduan Untuk Pemberdayaan Masyarakat. Jakarta: PT. Elex Media Komputindo.

Sinaga, M. 2001. Jamur merang dan budidaya. Edisi Revisi. Penerbit PT. Penebar Swadaya, Cimanggis-Depok,

Suharjo, Enjo. 2010. Bertanam jamur merang. Jakarta: PT. Agromedia Pustaka.

Suharto, Edi. 2014. Membangun Masyarakat Memberdayakan Rakyat: Kajian Startegis Pengembangan Kesejahteraan Sosial dan Pekerjaan Sosial, Bandung: Refika Aditama.

Sunandar, Bambang. 2010. Budidaya Jamur Merang. Pengembangan Teknologi Pertanian. 